\title{
NQ01 Gene
}

National Cancer Institute

\section{Source}

National Cancer Institute. NQ01 Gene. NCI Thesaurus. Code C18501.

This gene is involved in drug/xenobiotic metabolism, biosynthetic processes and the prevention of cellular oxidative stress. 